\title{
Assessment of Urokinase-Type Plasminogen Activator and Its Inhibitor PAI-1 in Breast Cancer Tissue: Historical Aspects and Future Prospects
}

\author{
Manfred Schmitt ${ }^{\mathrm{a}} \quad$ Karin Mengele $^{\mathrm{a}} \quad$ Apostolos Gkazepis $^{\mathrm{a}} \quad$ Rudolf Napieralskia $^{\mathrm{a}}$ \\ Viktor Magdolen ${ }^{a} \quad U^{2}$ Reuning ${ }^{a}$ Nadia Harbeck ${ }^{a, b}$ \\ ${ }^{a}$ Clinical Research Unit, \\ ${ }^{\text {b} D i v i s i o n ~ o f ~ S e n o l o g y, ~ D e p a r t m e n t ~ o f ~ O b s t e t r i c s ~ a n d ~ G y n e c o l o g y, ~ K l i n i k u m ~ r e c h t s ~ d e r ~ I s a r, ~ T e c h n i c a l ~ U n i v e r s i t y ~ o f ~ M u n i c h, ~ G e r m a n y ~}$
}

\section{The Early Days in Fibrinolysis Research}

The new Latin word fibrinolysis describes a process whereby a fibrin clot - the product of blood coagulation involving transformation of the liquid plasma protein fibrinogen into solidified fibrin - is lysed by proteolytic enzymes such as plasmin [1]. The serine protease plasmin is generated from the plasma protein plasminogen by the action of plasminogen activators, e.g. the tissue-type plasminogen activator (tPA) and the urokinase-type plasminogen activator (uPA) $[2,3]$. The proteolytic activity of plasmin is inactivated by alpha-2-antiplasmin or alpha-2macroglobulin, that of tPA or UPA essentially by two specific inhibitors, plasminogen activator inhibitor type-1 (PAI-1) and type-2 (PAI-2) [4]. These observations are not new; Astrup described plasminogen activator activity, fibrinolysin, in 1950, which at that time was a term for any of various proteolytic enzymes, especially plasmin, capable of digesting fibrin in the bloodstream $[5,6]$. It was only a few years earlier, in 1948, that MacFarlane and Biggs had reviewed previous work on the proteolytic factors of serum since different terms had been applied to identical substances, which had led to confusion [7]. The authors suggested that such names as serum trypsin, serum protease, serum tryptase, fibrinolysin, thrombolysin and others should be abandoned in favour of a more specific designation, and proposed adhering to a nomenclature suggested by Christensen and MacLeod in 1945 [8]. Here, the proteolytic enzyme of plasma is named plasmin, its precursor plasminogen, and its inhibitor antiplasmin. The term fibrinolysin was not recommended since this term was also applied to the streptococcal filtrate known to activate plasminogen in vivo. This filtrate factor became known as streptokinase.

Soon after, in 1951, Lewis and Ferguson [9] reported compounds capable of activating plasminogen in blood; in the same year, Williams [10] demonstrated the presence in urine of a substance (urokinase, uPA) able to activate plasminogen, which was later isolated from urine by Ploug et al. [11]. uPA is present in normal and malignant tissues and plasma as well, a fact which was recognised for ovarian cancer tissues in 1976 by Astedt and Holmberg [12] and a few years later (1982) for plasma by Wun et al. [13] and Tissot et al. [14]. The concentration of uPA in plasma amounts to about $3.5 \mathrm{ng} / \mathrm{ml}$, which is low compared to the relatively high concentration of $200-300 \mathrm{ng} / \mathrm{ml}$ in urine. Regarding the second major plasminogen activator, tPA, the prefix 'tissue-type' of tPA refers to the original observation in the 1940s that tPA is present in tissues and tissue extracts [3]. The con- centration of tPA in plasma amounts to $5-10 \mathrm{ng} / \mathrm{ml}$, but varies strongly under different physiological and pathological conditions.

Although it was already known before 1970 that plasminogen activator activity may be increased in tumour tissues over non-neoplastic tissue, for some time, interest was turned away from the possible role of plasminogen activators in cancer progression [15-20], particularly because the techniques used then did not distinguish between the two types of plasminogen activators, uPA and tPA [21,22]. In the years following Astedt and Holmberg's observation that uPA is released by human ovarian cancer cells, several other authors reported elevated uPA concentrations in tumour tissues compared to non-neoplastic tissues [23-26]. These observations prompted several investigators to restart detailed analyses of plasminogen activators, especially uPA, in tumour tissue and blood samples from cancer patients. Due to refined analytical tools and instruments, the structure of uPA, its proteolytic activation and role in the pathophysiology of tumour stroma degradation and tumour spread was investigated. This was also enhanced by the fact that, in 1985, a cell surface receptor for uPA (uPAR; CD87) was detected and it also became clear that the proteolytic activity of uPA and tPA in thrombolysis and fibrinolysis is counterbalanced by inhibitors of TPA and UPA and that UPAR is a focal adhesion point for localised uPA-mediated proteolysis in the physiological and malignant state $[27,28]$.

In 1966, Brakman et al. [29] described the presence of a plasminogen activator inhibitor in a group of patients with an impaired plasma fibrinolytic system, but it took another 18 years before the inhibitor PAI-1 was isolated [30]. The PAI-1 concentration in plasma is about $20 \mathrm{ng} / \mathrm{ml}$. The other inhibitor, PAI-2, was first detected in human placental tissue [31] and was therefore named placenta-type plasminogen activator inhibitor. Later it became clear that PAI-2 is also present in various types of white blood cells and in tumour tissue [32]. The PAI-2 concentrations in plasma are usually low, but can be high (above $35 \mathrm{ng} / \mathrm{ml}$ ) in pregnant women.

\section{Clinical Relevance of uPA and PAI-1: Historical Aspects}

The fundamental role of the uPA/PAI-1 system in tumour invasion and metastasis has first been derived from correlations between pathophysiological phenomena and tumour tissue-associated proteolytic activity. In essence, the finding was that plasminogen activators

\section{KARGER}

Fax +497614520714

Information@Karger.de

www.karger.com (c) 2008 S. Karger GmbH, Freiburg

Accessible online at:

www.karger.com/brc
Prof. Dr. Manfred Schmitt

Clinical Research Unit, Department of Obstetrics and Gynecology

Klinikum rechts der Isar, Technical University of Munich

Ismaninger Strasse 22, 81675 Munich, Germany

Tel. +49 89 4140-2427, Fax -7410

manfred.schmitt@lrz.tum.de 
are linked to degradation and remodeling of normal and cancer tissue and the surrounding extracellular matrix [2, 21, 22]. Concerning the clinical relevance of uPA, in 1985 O'Grady et al. [33] in a first comprehensive report determined total plasminogen activator proteolytic activity, uPA activity, and tPA activity in benign breast tumours and primary breast cancer. Benign tumours contained predominantly tPA activity whereas uPA activity was significantly higher in the malignant tumours compared with the benign ones. Then, in 1988, Duffy et al. [34] reported that patients with primary breast carcinomas containing high levels of uPA proteolytic activity had a significantly shorter disease-free interval than patients with low levels of activity. This finding led the authors to conclude that uPA may serve as a new prognostic marker in breast cancer. In the following years, Jänicke et al. [35, 36] presented evidence of a high correlation between elevated uPA antigen levels in the primary tumour and poor outcome of breast cancer patients, followed by a report of Jänicke et al. in 1991 [37] announcing that the same applies for the inhibitor of uPA, PAI-1, but not for tPA. Since then many independent reports applying antigen measurements (enzyme-linked immunosorbent assay (ELISA)) to quantify uPA and PAI-1 antigen content in cancer tissue extracts have been published describing such a correlation (table 1), not only for breast cancer but also for other solid malignant tumours $[2,38,39]$. These findings were important as such cancer biomarkers were urgently needed for the individualisation of oncologic therapy. Surveying the current literature (National Center for Biotechnology Information (NCBI) MedLine), it is evident that the majority of investigations has been conducted in breast cancer. In the years 1984 to July 2008, 762 articles (141 reviews) were listed in MedLine regarding the clinical relevance of uPA in cancer; for PAI-1, 536 articles ( 85 reviews). Regarding breast cancer, within that period of time, 336 articles ( 75 reviews) were listed in MedLine for uPA and 237 articles (48 reviews) for PAI-1. The peak of publications was between 2000 and 2003 (fig. 1).
Fig. 1. Number of publications related to uPA/PAI-1 and clinical relevance in breast cancer. A survey was conducted searching the NCBI MedLine database for publications listed between 1984 and July 2008. The first publication dealing with a possible clinical relevance of uPA in breast cancer was published in 1984 by O'Grady et al. [33], followed by a publication of Jänicke et al. in 1991 for PAI-1 [37].

\section{uPA as a Target for Therapy}

Given the now known biological importance of uPA and PAI-1 in tissue remodeling, angiogenesis, cell migration, and proliferation [40-42] - not only in the physiological but also in the pathophysiological state - and the clinical relevance of these cancer biomarkers for cancer prognosis and prediction of therapy response, several approaches have been developed targeting the uPA/PAI-1 system in cancer to reduce tumour invasion and metastasis. Such preclinical strategies include the use of antisense oligonucleotides or small interfering RNAs (siRNAs) to silence the uPA gene, antibodies to uPA or uPAR as well as recombinant or synthetic UPA or UPAR analogues to prevent binding of naturally occurring UPA (and UPA:PAI-1 complexes) to UPAR,

Table 1. Publications $(n=90)$ are listed that focus on the prognostic relevance (disease-free and/or overall survival) of uPA and/or PAI-1 antigen determined by enzymometric assay (ELISA) in breast cancer tissue extracts. Publications encompass breast cancer collectives from a large number of different countries. The principal authors are from 14 different countries: Germany: 21; The Netherlands: 15; France: 14; Denmark: 11; Ireland: 6; Japan: 5; Sweden: 5; Slovenia: 3; Canada: 2; Italy: 2; Switzerland: 2; USA: 2; New Zealand: 1; Spain: 1

\begin{tabular}{|c|c|c|c|c|}
\hline Factor & Reference & Year & Country & Number of patients \\
\hline uPA & Jänicke; Lancet 2:1049 & 1989 & Germany & 115 \\
\hline uPA & Duffy; Cancer Res 50:6827 & 1990 & Ireland & 166 \\
\hline uPA & Jänicke; Fibrinolysis 4:69 & 1990 & Germany & 115 \\
\hline uPA & Reilly; Blood Coagul Fibrinol 2:47 & 1991 & Ireland & 160 \\
\hline uPA, PAI-1 & Jänicke; Semin Thromb Hemost 17:303 & 1991 & Germany & 104 \\
\hline uPA, PAI-1 & Foucre; Br J Cancer 64:926 & 1991 & France & 87 \\
\hline $\mathrm{uPA}$ & $\mathrm{Ng}$; In Vivo 5:313 & 1991 & Canada & 63 \\
\hline uPA & Foekens; Cancer Res 52:6101 & 1992 & The Netherlands & 671 \\
\hline uPA & Spyratos; J Natl Cancer Inst 84:1266 & 1992 & France & 319 \\
\hline uPA, PAI-1 & Grondahl-Hansen; Cancer Res 53:2513 & 1993 & Denmark & 190 \\
\hline uPA, PAI-1 & Jänicke; BCRT 24:195 & 1993 & Germany & 247 \\
\hline uPA & Yamashita; Br J Cancer 67:374 & 1993 & Japan & 235 \\
\hline uPA & Yamashita; Br J Cancer 68:524 & 1993 & Japan & 144 \\
\hline uPA, PAI-1 & Bouchet; Bull Cancer 81:770 & 1994 & France & 314 \\
\hline uPA & Duffy; Cancer 74:2276 & 1994 & Ireland & 149 \\
\hline uPA, PAI-1 & Foekens; J Clin Oncol 12:1648 & 1994 & The Netherlands & 657 \\
\hline uPA, PAI-1 & Jänicke; Cancer Res 54:2527 & 1994 & Germany & 229 \\
\hline uPA & Romain; Br J Cancer 70:304 & 1994 & France & 249 \\
\hline uPA & Duggan; Int J Cancer 61:597 & 1995 & Ireland & 141 \\
\hline uPA, PAI-1 & Foekens; Cancer Res 55:1423 & 1995 & The Netherlands & 1012 \\
\hline uPA, PAI-1 & Foekens; J Natl Cancer Inst 87:751 & 1995 & The Netherlands & 235 \\
\hline uPA, PAI-1 & Grondahl-Hansen; Clin Cancer Res 1:1079 & 1995 & Denmark & 505 \\
\hline uPA & Yamashita; Surgery 117:601 & 1995 & Japan & 184 \\
\hline uPA & Fernö; Eur J Cancer 32A:793 & 1996 & Sweden & 688 \\
\hline uPA, PAI-1 & Fersis; GebFra 56:28 & 1996 & Germany & 155 \\
\hline
\end{tabular}


Table 1. continued

\begin{tabular}{|c|c|c|c|c|}
\hline Factor & Reference & Year & Country & Number of patients \\
\hline PAI-1 & Mayrhofer; GebFra 56:23 & 1996 & Germany & 197 \\
\hline uPA, PAI-1 & Grondahl-Hansen; BCRT 43:153 & 1997 & Denmark & 250 \\
\hline uPA, PAI-1 & Grondahl-Hansen; Clin Cancer Res 3:233 & 1997 & Denmark & 295 \\
\hline uPA, PAI-1 & Schmitt; Br J Cancer 76:306 & 1997 & Germany & 314 \\
\hline uPA & Shiba; J Cancer Res Clin Oncol 123:555 & 1997 & Japan & 226 \\
\hline uPA & Berns; J Clin Oncol 16:121 & 1998 & The Netherlands & 401 \\
\hline uPA & Bouchet; Br J Cancer 77:1495 & 1998 & France & 449 \\
\hline uPA & Duffy; Clin Chem 44:1177 & 1998 & Ireland & 184 \\
\hline uPA, PAI-1 & Eppenberger; J Clin Oncol 16:3129 & 1998 & Switzerland & 305 \\
\hline uPA, PAI-1 & Harbeck; Anticancer Res 18:2187 & 1998 & Germany & 100 \\
\hline uPA, PAI-1 & Kim; Clin Cancer Res 4:177 & 1998 & Japan & 130 \\
\hline uPA, PAI-1 & Knoop; Br J Cancer 77:932 & 1998 & Denmark & 429 \\
\hline uPA, PAI-1 & Kute; BCRT 47:9 & 1998 & USA & 168 \\
\hline uPA & Maguire; Int J Biol Markers 13:139 & 1998 & Ireland & 193 \\
\hline uPA, PAI-1 & Meijer-van Gelder; J Clin Oncol 17:1449 & 1998 & The Netherlands & 1630 \\
\hline uPA & Peyrat; Clin Cancer Res 4:189 & 1998 & France & 634 \\
\hline uPA, PAI-1 & Thomssen; Anticancer Res 18:2173 & 1998 & Germany & 103 \\
\hline uPA & Tetu; Hum Pathol 29:979 & 1998 & Canada & 586 \\
\hline uPA, PAI-1 & Bouchet; J Clin Oncol 17:3048 & 1999 & France & 499 \\
\hline uPA & Broët; Br J Cancer 80:536 & 1999 & France & 1245 \\
\hline uPA, uPA:PAI-1 & de Witte; Br J Cancer 79:1190 & 1999 & The Netherlands & 892 \\
\hline tPA, tPA:PAI-1 & de Witte; Br J Cancer 80:286 & 1999 & The Netherlands & 865 \\
\hline uPA, PAI-1 & Harbeck; BCRT 54:147 & 1999 & Germany & 316 \\
\hline uPA, PAI-1 & Harbeck; Br J Cancer 80:419 & 1999 & Germany & 125 \\
\hline uPA, PAI-1 & Harbeck; Int J Oncol 14:663 & 1999 & Germany & 112 \\
\hline uPA, PAI-1 & Meijer-van Gelder; J Clin Oncol 17:1449 & 1999 & The Netherlands & 1630 \\
\hline PAI-1 & Billgren; Eur J Cancer 36:1374 & 2000 & Sweden & 546 \\
\hline uPA & Ferrero-Poüs; Clin Cancer Res 6:4745 & 2000 & France & 488 \\
\hline uPA, PAI-1 & Foekens; Cancer Res 60:636 & 2000 & The Netherlands & 2780 \\
\hline uPA, PAI-1 & Fox; J Pathol 195:236 & 2000 & New Zealand & 136 \\
\hline uPA, PAI-1 & Harbeck; Int J Biol Markers 15:79 & 2000 & Germany & 276 \\
\hline uPA, PAI-1, uPA:PAI-1 & Pedersen; Cancer Res 60:6927 & 2000 & Denmark & 342 \\
\hline uPA, PAI-1 & Harbeck; Clin Cancer Res 7:2757 & 2001 & Germany & 276 \\
\hline uPA, PAI-1 & Jänicke; JNCI 93:913 & 2001 & Germany & 556 \\
\hline uPA, PAI-1 & Konecny; Clin Cancer Res 7:2448 & 2001 & USA & 587 \\
\hline uPA, PAI-1 & Malmstrom; J Clin Oncol 19:2010 & 2001 & Sweden & 237 \\
\hline uPA, PAI-1 & Meijer-van Gelder; BCRT 68:249 & 2001 & The Netherlands & 4114 \\
\hline uPA, PAI-1 & Romain; Int J Cancer 95:56 & 2001 & France & 237 \\
\hline uPA, PAI-1, uPA:PAI-1 & Sten-Linder; Anticancer Res 21:2861 & 2001 & Sweden & 233 \\
\hline uPA, PAI-1 & Borstnar; Clin Breast Cancer 3:138 & 2002 & Slovenia & 460 \\
\hline uPA, PAI-1 & Cufer; Int J Biol Markers 17:33 & 2002 & Slovenia & 766 \\
\hline uPA, PAI-1 & Harbeck; J Clin Oncol 20:1000 & 2002 & Germany & 761 \\
\hline uPA, PAI-1 & Harbeck; Cancer Res 62:4617 & 2002 & Germany & 3424 \\
\hline uPA, PAI-1 & Janz; Int J Cancer 97:278 & 2002 & Germany & 83 \\
\hline uPA, PAI-1 & Look; JNCI 94:116 & 2002 & The Netherlands & 8377 \\
\hline uPA, PAI-1 & Bouchet; Int J Biol Markers 18:207 & 2003 & France & 488 \\
\hline uPA, PAI-1 & Cufer; Int J Biol Markers 18:106 & 2003 & Slovenia & 460 \\
\hline uPA, PAI-1 & Dazzi; Cancer Invest 21:208 & 2003 & Italy & 81 \\
\hline uPA, PAI-1 & Hansen; Br J Cancer 88:102 & 2003 & Denmark & 228 \\
\hline uPA, PAI-1 & Schrohl; Mol Cell Prot 2:164 & 2003 & Denmark & 341 \\
\hline uPA, PAI-1 & Zemzoum; J Clin Oncol 21:1022 & 2003 & Germany & 128 \\
\hline uPA, PAI-1 & Dorssers; Clin Cancer Res 10:6194 & 2004 & The Netherlands & 2593 \\
\hline uPA, PAI-1, uPA:PAI-1 & Manders; Cancer 101:486 & 2004 & The Netherlands & 576 \\
\hline uPA, PAI-1, uPA:PAI-1 & Manders; Cancer Res 64:659 & 2004 & The Netherlands & 1119 \\
\hline uPA, PAI-1 & Meo; Int J Biol Markers 19:282 & 2004 & Italy & 196 \\
\hline uPA, PAI-1 & Schrohl; Clin Cancer Res 10:2289 & 2004 & Denmark & 2984 \\
\hline uPA & Zhou; Int J Biochem Cell Biol 37:1130 & 2005 & Switzerland & 59 \\
\hline uPA, PAI-1 & Desruisseau; Br J Cancer 94:239 & 2006 & France & 193 \\
\hline uPA, PAI-1 & Ryan; Ann Oncol 17:597 & 2006 & Germany & 420 \\
\hline uPA, PAI-1 & Castelló; Thromb Res 120:753 & 2007 & Spain & 70 \\
\hline uPA, PAI-1 & Offersen; Acta Oncol 46:782 & 2007 & Denmark & 438 \\
\hline uPA, PAI-1 & Descotes; Clin Breast Cancer 8:168 & 2008 & France & 732 \\
\hline uPA, PAI-1 & Linderholm; Breast May:26 & 2008 & Sweden & 219 \\
\hline PAI-1 & Offersen; Acta Oncol 47:618 & 2008 & Denmark & 408 \\
\hline
\end{tabular}


and naturally and synthetic serine protease inhibitors blocking uPA enzymatic activity to reduce tumour cell proliferation, invasion, and metastasis [2,43-46].

Drug candidates that emerged from synthetic uPA inhibitors shown to be effective in experimental tumour-bearing animals [46] are now in clinical phase I/II testing involving late-stage cancer patients afflicted with tumours of the breast, pancreas, ovary, or the gastrointestinal tract. Goldstein (this issue) reports the promising results of a phase Ib trial with the serine protease inhibitor WX-UK1 in patients with solid tumours, including breast cancer patients, in combination with the chemotherapeutic agent capecitabine. Also, WX-671 (MESUPRON ${ }^{\circledR}$, an oral pro-drug of WX-UK1) was studied in a phase Ib trial with patients with head and neck cancer (Lang et al., this issue). In July 2008, Wilex AG, Munich, Germany, successfully completed recruitment of a randomised clinical phase II trial of advanced pancreatic cancer patients. Patients were treated with MESUPRON in combination with the chemotherapeutic agent gemcitabine (Gemzar ${ }^{\circledR}$; Eli Lilly and Company, USA). MESUPRON is currently being tested clinically (phase II) in breast cancer patients in combination with the chemotherapeutic agent capecitabine.

\section{Clinical Impact of uPA and PAI-1 in Breast Cancer}

Over the years, substantial efforts have been made in breast cancer to subdivide patient populations into groups that behave differently, so that therapy can be applied more efficiently. Still, since these efforts are based on clinical outcomes related to clinical cancer size and the presence or absence of pathologically involved lymph nodes, subgroups with different biological behaviours cannot be defined correctly [47]. Nonetheless, in the last decade, basic and clinical scientists have studied a plethora of novel cancer biomarkers at the gene and protein level $[48,49]$. For breast cancer, several hundreds of such markers have been reported, yet only a handful have actually gained widespread clinical use, including the steroid hormone receptors estrogen receptor (ER) and progesterone receptor (PR), the oncogene HER2, and the tumour invasion factors UPA and PAI-1 [38, 50]. This lack of acceptance, due to controversial test results, at least in part comes from the biological diversity of the breast cancer disease, poorly designed or non-validated clinical studies, non-validated tools and test systems, poor statistics, and/or low quality of the tumour material tested.

The lack of contradictory evidence on the prognostic impact of uPA and PAI-1 is quite unique for any cancer biomarker and is remarkable considering the variety of demographic conditions covered by studies in Europe and abroad [38]. Table 1 depicts key references in which studies are described showing the prognostic impact of uPA and/or PAI-1 in primary breast cancer. It is worth mentioning that UPA and PAI-1 have reached the highest level of evidence (LOE-1) according to the tumour marker utility grading system [51] by fulfilling the criteria of a prospective therapy trial (Chemo-N0) to test the clinical utility of the two cancer biomarkers [52] and by a meta-analysis (pooled analysis) encompassing 8377 patients and published databases from 18 different study centres [53]. Finally, in November 2007, determining the uPA/PAI-1 content in a breast cancer patient's primary tumour tissue was incorporated into the breast cancer treatment guidelines of the American Society of Clinical Oncology (ASCO) to provide for the appropriate adjuvant systemic treatment [50].

It is worth mentioning that no significant correlation was found between plasma and tumour tissue levels of UPA and PAI-1, indicating that determination of these factors in plasma does not reflect their concentration in tumour tissue. Therefore, measurement of uPA and PAI-1 in blood cannot be recommended for assessing prognosis in breast cancer patients [54]
Techniques for the Determination of uPA and PAI-1 in Tumour Tissues

\section{Enzyme-Linked Immunosorbent Assay}

We would like to stress that so far, clinically relevant, validated data regarding uPA and PAI-1 in breast cancer have been obtained only by measuring these two cancer biomarkers by ELISA, either in tumour tissue cytosolic fractions or in the detergent-released tumour tissue fraction [54, 55]. Such ELISAs are commercially available (e.g. FEMTELLE ${ }^{\circledR}$; American Diagnostica Inc., Stamford, CT, USA) and robust enough for clinical routine use. The quality of the test kits is assessed and assured by the European Organization for Research and Treatment of Cancer (EORTC) PathoBiology Group (Brussels, Belgium). Use of the non-ionic detergent Triton X-100 for tumour tissue extraction is recommended since this method of extraction yields considerably more release of uPA antigen than uPA freed into the cytosol fraction. No such difference is observed for PAI-1 [55]. The test can be applied to primary tumour biopsies, core needle biopsies, and cryostat sections. Standard operating protocols for tumour tissue disintegration and $\mathrm{UPA} / \mathrm{PAI}-1$ test implementation are published and described explicitly $[56,57]$. Therefore, when evaluating other ways of determining uPA and PAI-1 in breast cancer tissue, the ELISA should be considered as the gold standard.

\section{Immunohistochemistry}

The use of fixed, archived paraffin-embedded tissue specimens, enabling more widely available determination of UPA and PAI-1, e.g. by applying specific antibodies in immunohistochemistry, is hampered by the fact that both UPA and PAI- 1 antigens are presented by tumour cells and surrounding stroma cells and that these biomarkers are released into the tissue as well, making reliable scoring rather difficult. Still, a first comparison of uPA values obtained by ELISA and by immunohistochemical score was already published in 1990 by Jänicke et al. [36]. A statistically significant increase in the uPA values determined by ELISA was noted with increasing staining intensity in immunohistochemistry. Such a correlation was also published for PAI-1 by Reilly et al. [58]. Various antibodies to uPA and PAI-1 generated in animals have been established and tested by different groups; an overview of published work describing distribution of the uPA/ PAI-1 antigens in breast cancer tumour tissue specimens is presented in table 2. Work is in progress utilising novel approaches to scan immunohistochemically stained breast cancer tumour tissue specimens by use of a high-resolution virtual microscope (figs. 2 and 3) combined with automatic image analysis systems. The aim of such studies is to provide an alternative to determination of UPA/PAI-1 in tumour tissue extracts by ELISA to allow worldwide quantification of these cancer biomarkers in routinely available breast cancer specimens, including preoperative core needle biopsies.

\section{mRNA and DNA Methylation}

Since assessment of uPA and PAI-1 expression status in breast cancer tumour tissues by ELISA requires fresh or fresh-frozen tissue, alternative methods of cancer biomarker analysis using formalin-fixed biopsy material have been investigated. One option is assessment of UPA and PAI-1 marker expression at the transcriptional level. Thus, recently, highly sensitive quantitative reverse transcription-polymerase chain reaction (RT-PCR) assays requiring only small amounts of mRNA and using formalin-fixed tissue specimens as the test material were established by Biermann et al. [59]. Interestingly, for uPA 
Table 2. A list of publications is presented dealing primarily with application of antibodies to uPA and/or PAI-1 to localise and/or quantify these cancer biomarkers in breast cancer tumour tissue specimens

\begin{tabular}{|c|c|c|c|c|c|}
\hline Factor & Reference & Year & Country & $\begin{array}{l}\text { Breast cancer } \\
\text { cases }\end{array}$ & Comments \\
\hline uPA & Jänicke; Fibrinolysis 4:69 & 1990 & Germany & 115 & $\begin{array}{l}\text { strong staining; independent prognostic factor for early } \\
\text { relapse; ELISA/IHC comparison }\end{array}$ \\
\hline PAI-1 & Reilly; Int J Cancer 50:208 & 1992 & Ireland & 43 & ELISA/IHC comparison for PAI-1 \\
\hline uPA & $\begin{array}{l}\text { Hildenbrand; Pathol Res } \\
\text { Pract 191:403 }\end{array}$ & 1995 & Germany & 42 & $\begin{array}{l}\text { correlation between microvessel density, } \\
\text { angioinvasion and uPA/PAI-1 levels; ELISA/IHC } \\
\text { comparison }\end{array}$ \\
\hline uPA & $\begin{array}{l}\text { Hildenbrand; Br J Cancer } \\
72: 818\end{array}$ & 1995 & Germany & 42 & $\begin{array}{l}\text { correlation between microvessel density, vascular } \\
\text { invasion, uPA level, macrophage content and } \\
\text { proliferation rate; ELISA/IHC comparison }\end{array}$ \\
\hline $\mathrm{uPA}$ & $\begin{array}{l}\text { Hubbard; Eur J Cancer } \\
\text { 31A:103 }\end{array}$ & 1995 & UK & 134 & $\begin{array}{l}\text { overexpression of uPA is not correlated with presence } \\
\text { or absence of ERs }\end{array}$ \\
\hline uPA & $\begin{array}{l}\text { Göhring; Anticancer Res } \\
\text { 16:1011 }\end{array}$ & 1996 & Germany & 281 & $58 \%$ positivity for uPA \\
\hline uPA & $\begin{array}{l}\text { Solomayer; Br J Cancer } \\
76: 812\end{array}$ & 1997 & Germany & 280 & $\begin{array}{l}\text { UPA-positive tumour: shorter metastasis-free interval; } \\
\text { poor prognosis for patients with both TAG12 and uPA } \\
\text { positivity, followed by TAG12 positivity; patients with } \\
\text { disseminated tumour cells: uPA-positivity correlated with } \\
\text { poor prognosis }\end{array}$ \\
\hline uPA, PAI-1 & Umeda; J Pathol 183:388 & 1997 & Japan & 73 & uPA associated with poor prognosis \\
\hline uPA & Kennedy; Br J Cancer 77:1638 & 1998 & Ireland & 36 & significant correlation between uPA and uPAR staining \\
\hline uPA, PAI-1 & $\begin{array}{l}\text { Ferrier; Br J Cancer } \\
\text { 79:1534 }\end{array}$ & 1999 & $\begin{array}{l}\text { The } \\
\text { Netherlands }\end{array}$ & 28 & $\begin{array}{l}\text { uPA, tPA, PAI-1 and uPAR expression levels assessed } \\
\text { by ELISA or IHC }\end{array}$ \\
\hline uPA, PAI-1 & $\begin{array}{l}\text { Jahkola; Br J Cancer } \\
\text { 80:167 }\end{array}$ & 1999 & Finland & 158 & $\begin{array}{l}\text { fibroblastic PAI-1 expression associated with local } \\
\text { recurrence and distant metastasis; diffuse stromal uPA } \\
\text { associated with local recurrence }\end{array}$ \\
\hline uPA, PAI-1 & $\begin{array}{l}\text { Dublin; Am J Pathol } \\
\text { 157:1219 }\end{array}$ & 2000 & UK & 142 & $\begin{array}{l}\text { significant association between strong expression of } \\
\text { uPA and uPAR and tumour size; in intraductal } \\
\text { carcinomas strong expression of UPA, uPAR, and PAI-1 }\end{array}$ \\
\hline uPA, PAI-1 & $\begin{array}{l}\text { Schneider; In Vivo } \\
\text { 14:507 }\end{array}$ & 2000 & Spain & 189 & $\begin{array}{l}\text { uPA:PAI-1 positivity correlated with ER expression, } \\
\text { PR expression, favourable nuclear grade }\end{array}$ \\
\hline uPA & Nielsen; Lab Invest 81:1485 & 2001 & Denmark & 31 & $\begin{array}{l}\text { close correlation between intensity of uPA immuno- } \\
\text { staining and uPA protein content measured by ELISA }\end{array}$ \\
\hline uPA & Tetu; Cancer 92:2957 & 2001 & Canada & 557 & $\begin{array}{l}\text { uPA positivity associated with poor outcome; high uPA } \\
\text { expression was associated with poor nuclear grade and } \\
\text { lack of hormone receptor content }\end{array}$ \\
\hline uPA, PAI-1 & $\begin{array}{l}\text { Alvarez-Millan; } \\
\text { Oncology 62:286 }\end{array}$ & 2002 & Spain & 28 & $\begin{array}{l}\text { PAI-1 reflects poor prognosis; uPA:PAI-1 complex } \\
\text { accumulation in tumour cells reflects good prognosis }\end{array}$ \\
\hline uPA, PAI-1 & $\begin{array}{l}\text { Zhao; Breast Cancer } \\
\text { 9:118 }\end{array}$ & 2002 & China/Japan & 20 & $\begin{array}{l}\text { PAI-1 in tumour cells associated with histological } \\
\text { grade; PAI-1 in stromal cells associated with } \\
\text { histological grade and comedo-type necrosis }\end{array}$ \\
\hline uPA, PAI-1 & $\begin{array}{l}\text { Schneider; Br J Cancer } \\
88: 96\end{array}$ & 2003 & Spain & 212 & $\begin{array}{l}\text { statistically significant interaction between the presence } \\
\text { of uPA:PAI-1 complexes and PR positivity for axillary } \\
\text { metastasis }\end{array}$ \\
\hline uPA, PAI-1 & $\begin{array}{l}\text { Castello; Thromb Res } \\
120: 753\end{array}$ & 2007 & Spain & 70 & $\begin{array}{l}\text { uPA/PAI- } 1 \text { mRNA and antigen levels increased } \\
\text { in N+ patients }\end{array}$ \\
\hline uPA, PAI-1 & $\begin{array}{l}\text { Haas; Virchow's Archive } \\
\text { 452:277 }\end{array}$ & 2007 & Germany & 55 & $\begin{array}{l}\text { fibroblastic inflammatory reaction around the biopsy } \\
\text { channel affects stromal uPA and PAI-1 expression, } \\
\text { which may lead to increased levels of uPA/PAI-1 in ELISA }\end{array}$ \\
\hline uPA, PAI-1 & $\begin{array}{l}\text { Minisini; Am J Clin } \\
\text { Pathol 128:112 }\end{array}$ & 2007 & Italy & 199 & $\begin{array}{l}\text { correlation between uPA and ER expression; negative } \\
\text { uPA expression associated with negative steroid } \\
\text { hormone receptor expression, high tumour grade, } \\
\text { and high proliferation index }\end{array}$ \\
\hline uPA & $\begin{array}{l}\text { Surowiak; Anticancer Res } \\
\text { 27:2917 }\end{array}$ & 2007 & Germany & 45 & $\begin{array}{l}\text { expression of uPA associated with overall and } \\
\text { relapse-free survival }\end{array}$ \\
\hline
\end{tabular}


Fig. 2. uPA protein expression in ductal invasive breast cancer. Brown: uPA antigen, blue: haematoxylin (nuclei). Scanned with a Hamamatsu NanoZoomer virtual microscope (Hamamatsu Instruments, Herrsching, Germany) at $400 \times$ magnification. Mouse monoclonal antibody \#3689 (American Diagnostica Inc., Stamford, CT, USA). No antigen retrieval applied. Peroxidase-based labeled streptavidin biotin (LSAB) method with chromogen 3,3'-diaminobenzidine (DAB).

and PAI-1, when assessing breast cancer cell lines, a significant correlation of transcript and antigen (protein) levels was noted; this, however, did not apply to breast cancer tissue samples, confirming earlier studies in which also no significant correlation of mRNA level with antigen expression was found. Spyratos et al. [60], by assessing breast cancer tissue specimens, found only borderline correlation of uPA antigen with mRNA expression but a significant correlation for PAI-1. Although these results point to the fact that for clinical decision-making the UPA/PAI-1 ELISAs cannot be replaced at present by UPA/PAI-1 mRNA determination, transcription level determination of these cancer biomarkers may have prognostic impact in certain patient subpopulations, for instance by predicting nodal status, malignant transformation, distant metastasis, disease recurrence, or disease-free survival. Significant differences in the topographical distribution of transcription and protein expression levels of uPA and PAI-1 were noted by Castello et al. [61] when comparing uPA/PAI-1 expression levels assessed by in situ hybridisation to those obtained by immunohistochemical analyses. Lamy et al. [62] used a very novel approach, nucleic acid sequence-based amplification (NASBA), and showed high concordance between NASBA and UPA/PAI-1 antigen expression determined by ELISA.

Although still a matter of debate, especially for PAI-1, transcription can also be influenced by genetic factors leading to nucleotide polymorphisms (e.g. $4 \mathrm{G} / 5 \mathrm{G}$ ) of the PAI-1 gene $[63,64]$. In contrast to these studies, Sternlicht et al. [65], screening more than 2500 tumour tissue samples of breast cancer patients, did not find such an association of PAI-1 polymorphism with mRNA levels and frequency differences between tumour and control collectives, and also no association with annual mortality rates between the different allele subsets. Thus, until now, allele assessment of the 4G/5G PAI-1 polymorphism shows no consistent association with clinical factors.

Epigenetics represents an additional level of gene transcription control [66]. Methylation of cytosine residues in so-called CpG dinucleotide repeats in specific gene promoter regions can influence transcriptional activity, associating methylated $\mathrm{CpGs}$ with transcriptional silencing of the respective gene. This mechanism is facilitated by a complex machinery of enzymes, including DNA methyl transferases (DNMTs), demethylases, methylated DNA binding proteins (MBDs) and histone-modifying enzymes, linking DNA methylation with transcriptional repressive chromatin status [65]. Since epigenetic markers are DNA based, assessment of DNA methylation markers can easily be carried out in formalin-fixed, paraffin-embedded biopsies using DNA array technology, sequencing, or PCR-based assays. Xing et al. [67] and Gao et al. [68] showed an association of uPA and PAI-1 pro-
Fig. 3. PAI-1 protein expression in ductal invasive breast cancer. Brown: PAI-1 antigen, blue: haematoxylin (nuclei). Scanned with a Hamamatsu NanoZoomer virtual microscope (Hamamatsu Instruments, Herrsching, Germany) at $400 \times$ magnification. Mouse monoclonal antibody \#3785 (Ame-

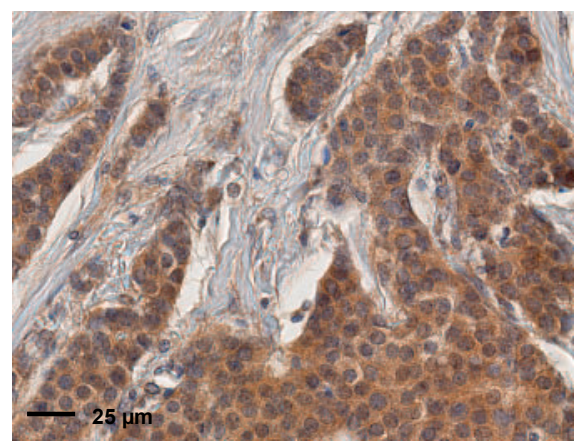
rican Diagnostica Inc., Stamford, CT, USA). No antigen retrieval applied. Peroxidase-based LSAB method with chromogen DAB.

moter methylation status with respective mRNA expression in breast cancer cell lines and an association with invasive capacity, which could be modulated by methylating (S-adenosylmethionine, SAM), demethylating (5-azacytidine, decitabine), or histone deacetylase-inhibiting drugs (Trichostatin, TSA). In breast cancer tissues, Pakneshan et al. [69] found a strong correlation of uPA DNA methylation status with its respective mRNA levels and increased demethylation of the promoter region with increasing tumour grading. New approaches for silencing of uPA or PAI-1 transcription involve RNA interference (short hairpin RNA (shRNA), antisense RNA) as demonstrated by Meyret-Figuieres et al. [70], Arens et al. [71], and Ishii et al. [72]. Future breast cancer studies may thus, in addition to uPA/PAI-1 antigen and mRNA measurements, consider assessment of nucleotide modifications and epigenetic variations of the uPA/PAI-1 genes to provide additional clinical information eventually leading to improved management of the breast cancer disease.

\section{Conclusions}

The cancer biomarkers uPA and PAI-1 are linked to tumour invasion and metastasis in patients afflicted with solid malignant tumours, such as breast cancer. The prognostic and predictive value of these proteolytic factors was shown in numerous validated retrospective and prospective studies, including a multicentre clinical trial (Chemo-N0). Thus, UPA and PAI-1 were awarded the highest level of evidence, LOE-1, based on the ASCO tumour marker utility grading system. So far, most of the clinically relevant data have been collected by quantitatively determining the uPA and PAI- 1 antigens contents in primary breast cancer tumour tissue extracts by certified ELISA tests. Although these tests are highly validated and quality-assured, alternative techniques not requiring fresh-frozen tissue are currently being explored. So far, none of the alternative ways of assessment at the gene or protein level has yielded satisfactory results, but research in this direction is encouraged. In particular, improved immunohistochemistry formats and quantitative assessment of epigenetic modifications of UPA and PAI-1 may provide new tools and vistas to determine these important cancer biomarkers even in small tissue samples such as core needle biopsies or single cells. Comparison of the clinical impact of UPA and PAI-1 in breast cancer to breast cancer mRNA signatures, such as the Amsterdam 70-gene signature (Mammaprint $\left.{ }^{\circledR}\right)$, the Rotterdam 76-gene signature, the Oncotype DX ${ }^{\circledR}$, or the $\mathrm{H} / \mathrm{I}$ signature, have not yet been published $[73,74]$. 


\section{References}

1 Cesarman-Maus G, Hajjar KA: Molecular mechanisms of fibrinolysis. Br J Haematol 2005;129:307321.

2 Schmitt M, Harbeck N, Thomssen C, Wilhelm O, Magdolen V, Reuning U, Ulm K, Höfler H, Jänicke F, Graeff H: Clinical impact of the plasminogen activation system in tumour invasion and metastasis: prognostic relevance and target for therapy. Thromb Haemost 1997;78:285-296.

3 Rijken DC: Plasminogen activators and plasminogen activator inhibitors: biochemical aspects. Baillieres Clin Haematol 1995;8:291-312.

4 Nijziel MR, van Oerle R, Hillen HF, Hamulyák K: From Trousseau to angiogenesis: the link between the haemostatic system and cancer. Neth J Med 2006;64:403-410.

$\checkmark 5$ Astrup T: Blood clotting and related processes. Adv Enzymol Relat Subj Biochem 1950;10:1-49.

6 Astrup T, Crookston J, Macintyre A: Proteolytic enzymes in blood. Acta Physiol Scand 1950;21:238 249

7 MacFarlane RG, Biggs R: Fibrinolysis. Its mechanism and significance. Blood 1948;13:1167-1187.

8 Christensen LR, MacLeod CM: A proteolytic enzyme of serum: characterisation, activation, and reaction with inhibitors. J Gen Physiol 1945;28:559.

9 Lewis JH, Ferguson JH: Studies on a proteolytic enzyme system of the blood. Activation of profibrinolysin by serum fibrinolysokinase. Proc Soc Exp Biol Med 1951;78:184-188.

10 Williams JR: The fibrinolytic activity of urine. Br J Exp Pathol 1951;32:530-537.

11 Ploug J, Kjeldgaard NO: Isolation of a plasminogen activator (urokinase) from urine. Arch Biochem Biophys 1956;62:500-501.

12 Astedt B, Holmberg L: Immunological identity of urokinase and ovarian carcinoma plasminogen activator released in tissue culture. Nature 1976;261: 595-597.

13 Wun TC, Schleuning WD, Reich E: Isolation and characterization of urokinase from human plasma. J Biol Chem 1982;257:3276-3283.

14 Tissot JD, Schneider P, Hauert J, Ruegg M, Kruithof $\mathrm{EK}$, Bachmann F: Isolation from human plasma of a plasminogen activator identical to urinary high molecular weight urokinase. J Clin Invest 1982;70 1320-1323.

15 Andersson L: Fibrinolysis in patients with prostatic cancer. Acta Chir Scand 1963;126:172-183.

16 McNicol GP, Douglas AS: Epsilon-aminocaproic acid and other inhibitors of fibrinolysis. Br Med Bull 1964;20:233-239.

17 MacFarlane RG: The development of ideas on fibrinolysis. Br Med Bull 1964;20:173-178.

18 Sharp AA: Pathological fibrinolysis. Br Med Bull 1964;20:240-246.

19 Johnson AJ, Newman J: The fibrinolytic system in health and disease. Semin Hematol 1964;117:401431.

20 Davidson JF, McNicol GP, Frank GL, Anderson TJ, Douglas AS: Plasminogen-activator-producing tumour. Br Med J 1969;1:88-91.

21 Schmitt M, Jänicke F, Graeff H: Tumour-associated proteases. Fibrinolysis 1992;6(suppl 4):3-26.

22 Dano K, Andreasen PA, Grondahl-Hansen J, Kristensen P, Nielsen LS, Skriver L: Plasminogen activators, tissue degradation, and cancer. Adv Cancer Res 1985;44:139-266.

23 Wu M, Arimura GK, Yunis AA: Purification and characterization of a plasminogen activator secreted by cultured human pancreatic carcinoma cells. Biochemistry 1977;16:1908-1913.
4 Svanberg L, Astedt B: Release of plasminogen activator from normal and neoplastic endometrium. Experientia 1979;35:818-819.

25 Markus G, Takita H, Camiolo SM, Corasanti JG, Evers JL, Hobika GH: Content and characterization of plasminogen activators in human lung tumours and normal lung tissue. Cancer Res 1980;40: 841-848.

26 Corasanti JG, Celik C, Camiolo SM, Mittelman A, Evers JL, Barbasch A, Hobika GH, Markus G: Plasminogen activator content of human colon tumours and normal mucosae: separation of enzymes and partial purification. J Natl Cancer Inst 1980;65: 345-351.

27 Vassalli JD, Baccino D, Belin D: A cellular binding site for the Mr 55,000 form of the human plasminogen activator, urokinase. J Cell Biol 1985;100:86-92.

28 del Rosso M, Dini G, Fibbi G: Receptors for plasminogen activator, urokinase, in normal and Rous sarcoma virus-transformed mouse fibroblasts. Cancer Res 1985;45:630-636.

29 Brakman P, Mohler ER, Astrup T: A group of patients with impaired plasma fibrinolytic system and selective inhibition of tissue activator-induced fibrinolysis. Scand J Haematol 1966;3:389-398.

30 Van Mourik JA, Lawrence DA, Loskutoff DJ: Purification of an inhibitor of plasminogen activator (antiactivator) synthesized by endothelial cells. J Biol Chem 1984;259:14914-14921.

31 Kawano T, Morimoto K, Uemura Y: Urokinase inhibitor in human placenta. Nature 1968;217:253-254.

32 Kruithof EK, Baker MS, Bunn CL: Biological and clinical aspects of plasminogen activator inhibitor type 2. Blood 1995;86:4007-4024.

33 O'Grady P, Lijnen HR, Duffy MJ: Multiple forms of plasminogen activator in breast tumours. Cancer Res 1985;45:6216-6218.

34 Duffy M, O'Grady P, Devaney D, O'Siorain L, Fennelly JJ, Lijnen HJ: Urokinase-plasminogen activator, a marker for aggressive breast carcinomas. Cancer 1988;62:531-533.

35 Jänicke F, Schmitt M, Ulm K, Gössner W, Graeff H: Urokinase-type plasminogen activator antigen and early relapse in breast cancer. Lancet 1989;2:1049.

-36 Jänicke F, Schmitt M, Hafter R, Hollrieder A, Babic R, Ulm K, Gössner W, Graeff H: The urokinasetype plasminogen activator (u-PA) is a potent predictor of early relapse in breast cancer. Fibrinolysis 1990;4:69-78.

37 Jänicke F, Schmitt M, Graeff H: Clinical relevance of the urokinase-type and tissue-type plasminogen activators and of their type 1 inhibitor in breast cancer. Semin Thromb Hemost 1991;17:303-312.

38 Harbeck N, Schmitt M, Paepke S, Allgayer H, Kates RE: Tumour-associated proteolytic factors uPA and PAI-1: critical appraisal of their clinical relevance in breast cancer and their integration into decisionsupport algorithms. Crit Rev Clin Lab Sci 2007;44: 179-201.

39 Laufs S, Schumacher J, Allgayer H: Urokinase-receptor (u-PAR): an essential player in multiple games of cancer: a review on its role in tumour progression, invasion, metastasis, proliferation/dormancy, clinical outcome and minimal residual disease. Cell Cycle 2006;5:1760-1771

40 Mondino A, Blasi F: uPA and uPAR in fibrinolysis, immunity and pathology. Trends Immunol 2004;25: 450-455.

41 Blasi F, Carmeliet P: uPAR: a versatile signalling orchestrator. Nat Rev Mol Cell Biol 2002;3:932-943.

42 Preissner KT, Kanse SM, May AE: Urokinase receptor: a molecular organizer in cellular communication. Curr Opin Cell Biol 2000;12:621-628.
43 Muehlenweg B, Sperl S, Magdolen V, Schmitt M, Harbeck N: Interference with the urokinase plasminogen activator system: a promising therapy concept for solid tumours. Expert Opin Biol Ther 2001; 1:683-691.

44 Lakka SS, Gondi CS, Rao JS: Proteases and glioma angiogenesis. Brain Pathol 2005;15:327-341.

45 Schmitt M, Wilhelm OG, Reuning U, Krüger A, Harbeck N, Lengyel E, Graeff H, Gänsbacher B, Kessler H, Bürgle M, Stürzebecher J, Sperl S, Magdolen V: The urokinase plasminogen activator system as a novel target for tumour therapy. Fibrinol Proteol 2000;14:114-132.

46 Setyono-Han B, Stürzebecher J, Schmalix WA, Muehlenweg B, Sieuwerts AM, Timmermans M, Magdolen V, Schmitt M, Klijn JG, Foekens JA: Suppression of rat breast cancer metastasis and reduction of primary tumour growth by the small synthetic urokinase inhibitor WX-UK1. Thromb Haemost 2005;93:779-786.

47 Hayes DF: Prognostic and predictive factors revisited. Breast 2005;14:493-499.

48 Sotiriou C, Piccart MJ: Taking gene-expression profiling to the clinic: when will molecular signatures become relevant to patient care? Nat Rev Cancer 2007; 7:545-553.

49 Hinestrosa MC, Dickersin K, Klein P, Mayer M, Noss K, Slamon D, Sledge G, Visco FM: Shaping the future of biomarker research in breast cancer to ensure clinical relevance. Nat Rev Cancer 2007;7: 309-315.

50 Harris L, Fritsche H, Mennel R, Norton L, Ravdin P, Taube S, Somerfield MR, Hayes DF, Bast RC Jr; American Society of Clinical Oncology: American Society of Clinical Oncology 2007 update of recommendations for the use of tumour markers in breast cancer. J Clin Oncol 2007;25:5287-5312.

51 Hayes DF, Bast RC, Desch CE, Fritsche H Jr, Kemeny NE, Jessup JM, Locker GY, Macdonald JS, Mennel RG, Norton L, Ravdin P, Taube S, Winn RJ: Tumour marker utility grading system: a framework to evaluate clinical utility of tumour markers. J Natl Cancer Inst 1996;88:1456-1466.

52 Jänicke F, Prechtl A, Thomssen C, Harbeck N, Meisner C, Untch M, Sweep CG, Selbmann HK Graeff H, Schmitt M; German N0 Study Group: Randomized adjuvant chemotherapy trial in highrisk, lymph node-negative breast cancer patients identified by urokinase-type plasminogen activator and plasminogen activator inhibitor type 1 . J Natl Cancer Inst 2001;93:913-920.

53 Look MP, van Putten WL, Duffy MJ, Harbeck N, Christensen IJ, Thomssen C, Kates R, Spyratos F, Fernö M, Eppenberger-Castori S, Sweep CG, Ulm K, Peyrat JP, Martin PM, Magdelenat H, Brünner N, Duggan C, Lisboa BW, Bendahl PO, Quillien V, Daver A, Ricolleau G, Meijer-van Gelder ME, Manders P, Fiets WE, Blankenstein MA, Broët P, Romain S, Daxenbichler G, Windbichler G, Cufer T, Borstnar S, Kueng W, Beex LV, Klijn JG, O'Higgins N, Eppenberger U, Jänicke F, Schmitt M, Foekens JA: Pooled analysis of prognostic impact of urokinase-type plasminogen activator and its inhibitor PAI-1 in 8377 breast cancer patients. J Natl Cancer Inst 2002;94:116-128.

54 Grebenchtchikov N, Maguire TM, Riisbro R, Geurts-Moespot A, O'Donovan N, Schmitt M, McGreal G, McDermott E, O'Higgins N, Brünner N, Sweep CG, Duffy MJ: Measurement of plasminogen activator system components in plasma and tumour tissue extracts obtained from patients with breast cancer: an EORTC Receptor and Biomarker Group collaboration. Oncol Rep 2005;14:235-239. 
55 Jänicke F, Pache L, Schmitt M, Ulm K, Thomssen $\mathrm{C}$, Prechtl A, Graeff $\mathrm{H}$ : Both the cytosols and detergent extracts of breast cancer tissues are suited to evaluate the prognostic impact of the urokinasetype plasminogen activator and its inhibitor, plasminogen activator inhibitor type 1 . Cancer Res 1994;54:2527-2530.

56 Schmitt M, Sturmheit AS, Welk A, Schnelldorfer C, Harbeck N: Procedures for the quantitative protein determination of urokinase and its inhibitor, PAI-1, in human breast cancer tissue extracts by ELISA. Methods Mol Med 2006;120:245-265.

57 Schmitt M, Mengele K, Schueren E, Sweep FC, Foekens JA, Brünner N, Laabs J, Malik A, Harbeck $\mathrm{N}$; European Organisation for Research and Treatment of Cancer Pathobiology Group: European Organisation for Research and Treatment of Cancer (EORTC) Pathobiology Group standard operating procedure for the preparation of human tumour tissue extracts suited for the quantitative analysis of tissue-associated biomarkers. Eur J Cancer 2007;43:835-844.

58 Reilly D, Christensen L, Duch M, Nolan N, Duffy MJ, Andreasen PA: Type-1 plasminogen activator inhibitor in human breast carcinomas. Int J Cancer 1992;50:208-214.

-59 Biermann JC, Holzscheiter L, Kotzsch M, Luther T, Kiechle-Bahat M, Sweep FC, Span PN, Schmitt M, Magdolen V: Quantitative RT-PCR assays for the determination of urokinase-type plasminogen activator and plasminogen activator inhibitor type 1 mRNA in primary tumour tissue of breast cancer patients: Comparison to antigen quantification by ELISA. Int J Mol Med 2008;21:251-259.
60 Spyratos F, Bouchet C, Tozlu S, Labroquere M, Vignaud S, Becette V, Lidereau R, Bieche I: Prognostic value of uPA, PAI-1 and PAI-2 mRNA expression in primary breast cancer. Anticancer Res 2002;22: 2997-3003.

61 Castello R, Landete JM, Espana F, Vazquez C, Fuster C, Almenar SM, Ramon LA, Radtke KP, Estelles A: Expression of plasminogen activator inhibitors type 1 and type 3 and urokinase plasminogen activator protein and mRNA in breast cancer. Thromb Res 2007;120:753-762.

62 Lamy PJ, Verjat T, Servanton AC, Paye M, Leissner P, Mougin B: Urokinase-type plasminogen activator and plasminogen activator inhibitor type-1 mRNA assessment in breast cancer by means of NASBA: Correlation with protein expression. Am J Clin Pathol 2007;128:404-413.

63 Zhang X, Shu XO, Cai Q, Ruan Z, Gao YT, Zheng W: Functional plasminogen activator inhibitor-1 gene variants and breast cancer survival. Clin Cancer Res 2006;12:6037-6042.

64 Castello R, Espana F, Vazquez C, Fuster C, Almenar SM, Aznar J, Estelles A: Plasminogen activator inhibitor-1 4G/5G polymorphism in breast cancer patients and its association with tissue PAI-1 levels and tumour severity. Thromb Res 2006;117:487-492.

65 Sternlicht MD, Dunning AM, Moore DH, Pharoah PD, Ginzinger DG, Chin K, Gray JW, Waldman FM, Ponder BA, Werb Z: Prognostic value of PAI1 in invasive breast cancer: Evidence that tumourspecific factors are more important than genetic variation in regulating PAI1 expression. Cancer Epidemiol Biomarkers Prev 2006;15:2107-2114.

66 Esteller M: Epigenetics in cancer. N Engl J Med 2008;358:1148-1159.
67 Xing RH, Rabbani SA: Transcriptional regulation of urokinase (uPA) gene expression in breast cancer cells: Role of DNA methylation. Int J Cancer 1999; 81:443-450.

68 Gao S, Skeldal S, Krogdahl A, Sorensen JA, Andreasen PA: CpG methylation of the PAI-1 gene 5' flanking region is inversely correlated with PAI-1 mRNA levels in human cell lines. Thromb Haemost 2005;94:651-660.

69 Pakneshan P, Tetu B, Rabbani SA: Demethylation of urokinase promoter as a prognostic marker in patients with breast carcinoma. Clin Cancer Res 2004;10:3035-3041.

70 Meryet-Figuieres M, Resina S, Lavigne C, BarlovatzMeimon G, Lebleu B, Thierry AR: Inhibition of PAI-1 expression in breast cancer carcinoma cells by siRNA at nanomolar range. Biochimie 2007;89: 1228-1233.

71 Arens N, Gandhari M, Bleyl U, Hildenbrand R: In vitro suppression of urokinase plasminogen activator in breast cancer cells - a comparison of two antisense strategies. Int J Oncol 2005;26:113-119.

72 Ishii T, Fujishiro M, Masuda M, Teramoto S, Matsuse T: A methylated oligonucleotide induced methylation of GSTP1 promoter and suppressed its expression in A549 lung adenocarcinoma cells. Cancer Lett 2004;212:211-223.

73 Marchionni L, Wilson RF, Wolff AC, Marinopoulos S, Parmigiani G, Bass EB, Goodman SN: Systematic review: gene expression profiling assays in early-stage breast cancer. Ann Intern Med 2008;148:358-369.

74 Wang Y, Klijn JG, Zhang Y, Sieuwerts AM, Look MP, Yang F, Talantov D, Timmermans M, Meijervan Gelder ME, Yu J, Jatkoe T, Berns EM, Atkins D, Foekens JA: Gene-expression profiles to predict distant metastasis of lymph-node-negative primary breast cancer. Lancet 2005;365:671-679. 